\title{
THE INFLUENCE OF INFILTRATION OF LEACHATE FROM LANDFILLS ON THE CHANGES OF CHEMICAL PARAMETERS OF THE SOIL
}

\author{
Grzegorz Gałko
}

1 Department of Technologies and Installations for Waste Management, Faculty of Energy and Environmental Engineering, Silesian University of Technology, Konarskiego 18, 44-100 Gliwice, Poland, e-mail: grzegorz. galko@polsl.pl

Received: 2015.06.17

Accepted: 2015.08.31 Published: 2015.10.01

\begin{abstract}
The article presented the results of geochemical research of clean soil and soil contaminated with the leachate from the landfill. Two types of soil were studied - brown with a stony foundation and loamy. The aim of the research was to compare the impact of leachate infiltration on the changes of chemical parameters of soils and to determine their buffer properties and susceptibility to contamination on this basis. The obtained results showed that the total acidity, mineral alkalinity and chloride content in the studied soils reduced after the contamination with the landfill leachate. While the chloride content, general hardness and general alkalinity increased. It has been found that the effect of infiltration of the landfill leachate was the significant reduction of mineral substances due to their washout of the soil profile. It has also been shown that the studied landfill leachate contained substantial quantities of substances favourable to the plant growth.
\end{abstract}

Keywords: landfill, leachate, infiltration, loamy soil, brown soil,

\section{INTRODUCTION}

The harmfulness of the impact of the landfill on the environment manifests mostly due to the leachate, dust and odours [Bojanowicz-Bablok 2012]. In particular, a major threat to the hydrogeological sphere are the leachate due to infiltration to the soil. The effect is the deterioration of quality parameters of the soil in the landfill region. The scale of this threat depends on the size of the area surface of this landfill, technical infrastructure and the type of soil. Research results presented in the article show changes of chemical parameters on the result of the leachate infiltration from the environment for the brown soil on the stony ground and loamy soil.

Landfills are also cumbersome due to the presence of animals (foxes, martens, dogs, insects, birds and rodents) migrating to the environment in order to search food and lugging trash around the area. For this reason, there are numerous protests of the local residents leading to blocking the investments in new landfills or delays in the modernisation of the existing ones [BojanowiczBablok 2012].

The impact on the communal waste landfill environment depends on its structure and security, as well as the amount, type and quality of accumulated waste. The most frequently collected wastes include: paper, metals, glass, cardboard and biodegradable waste. The mass of deposited waster in the landfill undergoes a lot of changes of the biochemical and chemical nature involving water (e.g. precipitation) what results in the creation of significant amounts of contaminated leachate [Renou et. al.2008].

The leachate circulation depends on the way of water migration in the landfill. The increase in rainfall contributes to the dilution of pollutants and as a result to the reduction of concentrations, what causes an increase in volume. The landfill leachate, through infiltration poses a real danger to the soil solution. It is a way strictly linked with the morphological composition of waste mixture [Koc-Jurczyk 2011]. The landfill requires security against the infiltration of leachate to the envi- 
ronment. For this purpose the geomembranes and sealing mats are used, which are resistant to the concentrated waste from the landfill, preventing the entry to the soil.

\section{MATERIALS}

\section{The leachate from the communal waste landfill in Knurów}

The research used the leachate from the communal waste landfill in Knurów. Its negative impact is caused due to the increased contents of ions, solutes and suspensions, affecting the composition of the soil solution (liquid soil phases), soil air (gas soil phases), but also the phase of constant soil.

The values of contamination indicators in the leachate from the communal waste landfill in Knurów were determined based on the permit of the Silesian Province Governor ŚR-III-6618/ PZ/43/18/06 of July 14, 2006 are presented in Table 1.

The data show that some leachate parameters significantly differ from the permissible values. Exceeding, even multiple, of the limit values for sewage introduced to water and soil, in particular applies to:

- biochemical oxygen demand,

- electrolytic conductivity,
- chemical oxygen demand,

- ammonium nitrogen,

- chlorides,

- substances extracted by petroleum ether,

The assessment of the presented data confirms the need for undertaking research of the effect of the leachate infiltration from the considered landfill on chemical properties of soils.

\section{Brown soil on stony ground}

The brown soil on stony ground samples were taken for the research. The place of sampling was the forest complex in the district of Cieszyn in the rural area of Brenna [Mayer2014, Barański1995]. The slope of a two-top mountain Lipowski Gron was selected, with a height of $734 \mathrm{~m}$ above sea level constituting the end of the Równica chain. The analysis used the soil at a depth of $40-50 \mathrm{~cm}$ below ground level, including levels: O-organic, P-humus, K-root [Barański 1995]. The collected soil stood out in colour - from brown-gray to dark gray [Zawadzki 1999]. Moreover, the outstanding feature of the soil was the large content of dead plant parts and rock fragments (Figure 1).

\section{Loamy soil}

The sampling place of the loamy soil for the research was the area surrounding the forest

Table 1. Values of chemical parameters of the studied leachate compared to the permissible values [PPHU Komar 2014]

\begin{tabular}{|c|c|c|c|}
\hline Parameter & Value of chemical parameter: & Limit value* & Transgression \\
\hline $\mathrm{pH}$ & $6.5-9$ & $6.5-9$ & $0 \%$ \\
\hline electrolytic conductivity & $20000 \mu \mathrm{S} / \mathrm{cm}$ & $2500 \mu \mathrm{S} / \mathrm{cm}$ & $800 \%$ \\
\hline total suspended solids & $500 \mathrm{mg} / \mathrm{l}$ & $35 \mathrm{mg} / \mathrm{l}$ & $1428 \%$ \\
\hline BOD & $500 \mathrm{mg} \mathrm{O}_{2} / \mathrm{dm}^{3}$ & $25 \mathrm{mg} \mathrm{O}_{2} / \mathrm{dm}^{3}$ & $2000 \%$ \\
\hline COD & $2000 \mathrm{mgO}_{2} / \mathrm{dm}^{3}$ & $125 \mathrm{mgO}_{2} / \mathrm{dm}^{3}$ & $1600 \%$ \\
\hline Chlorides & $3000 \mathrm{mg} / \mathrm{dm}^{3}$ & $1000 \mathrm{mg} / \mathrm{dm}^{3}$ & $300 \%$ \\
\hline Sulphuroeous & $500 \mathrm{mg} / \mathrm{dm}^{3}$ & $500 \mathrm{mg} / \mathrm{dm}^{3}$ & $0 \%$ \\
\hline Ammonia Nitrogen & $200 \mathrm{mg} / \mathrm{dm}^{3}$ & $10 \mathrm{mg} / \mathrm{dm}^{3}$ & $2000 \%$ \\
\hline Zinc & $1 \mathrm{mg} / \mathrm{dm}^{3}$ & $2 \mathrm{mg} / \mathrm{dm}^{3}$ & $0 \%$ \\
\hline Lead & $0.1 \mathrm{mg} / \mathrm{dm}^{3}$ & $0.1 \mathrm{mg} / \mathrm{dm}^{3}$ & $0 \%$ \\
\hline Copper & $0.1 \mathrm{mg} / \mathrm{dm}^{3}$ & $0.1 \mathrm{mg} / \mathrm{dm}^{3}$ & $0 \%$ \\
\hline Chrome overall & $0.1 \mathrm{mg} / \mathrm{dm}^{3}$ & $0.1 \mathrm{mg} / \mathrm{dm}^{3}$ & $0 \%$ \\
\hline Mercury & $0.05 \mathrm{mg} / \mathrm{dm}^{3}$ & $0.06 \mathrm{mg} / \mathrm{dm}^{3}$ & $0 \%$ \\
\hline substances extracted with petroleum ether & $100 \mathrm{mg} / \mathrm{dm}^{3}$ & $50 \mathrm{mg} / \mathrm{dm}^{3}$ & $200 \%$ \\
\hline Petroleum substances & $15 \mathrm{mg} / \mathrm{dm}^{3}$ & $15 \mathrm{mg} / \mathrm{dm}^{3}$ & $0 \%$ \\
\hline
\end{tabular}

* Regulation of the Minister of Environment of July 24, 2006 on the conditions which should be met while introducing sewage to waters or to the soil, and on substances particularly harmful to the aquatic environment (Journal of Laws 2006 no. 137. item 984). 


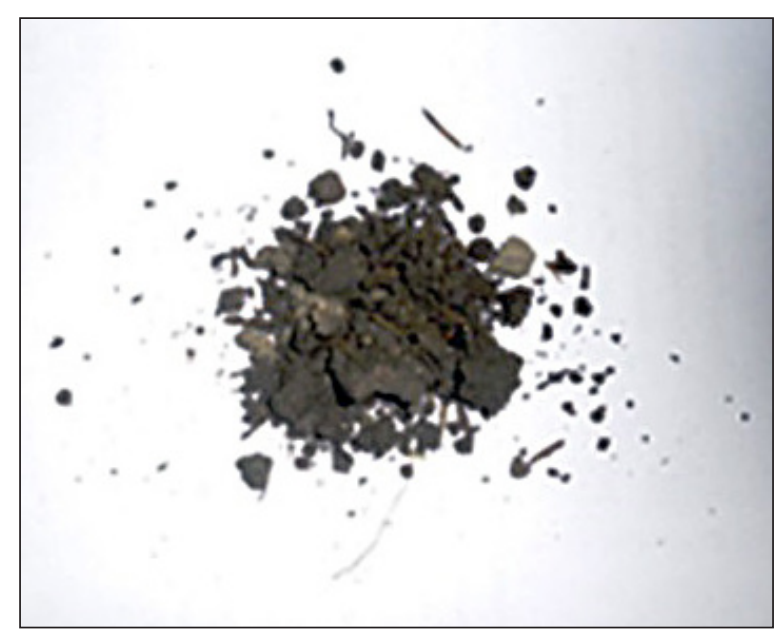

Figure 1. The view of brown soil samples on stony ground (photo G. Gałko)

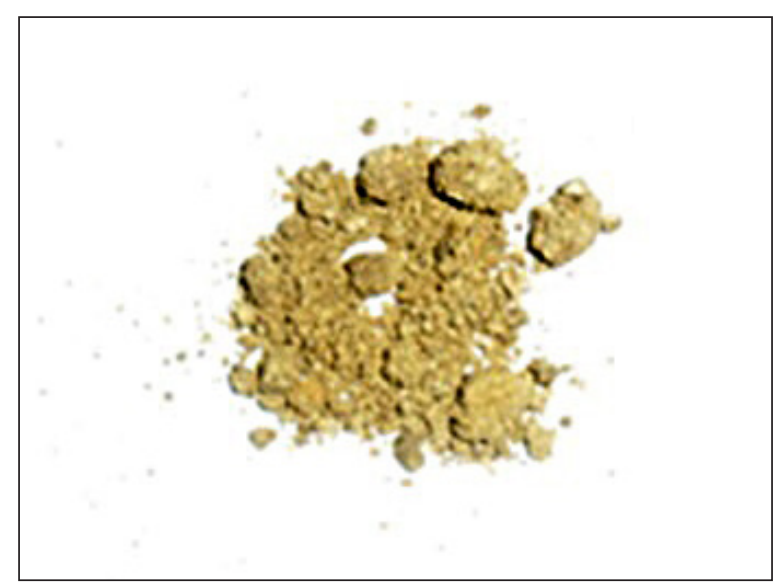

Figure 2. The view of the loamy soil sample (photo G. Gałko)

area called the Katowice Forest Park (in the past customarily known as the Three Ponds Valley), within the district of Katowice Brynów. This area is the element of the so-called forest area of the protective strip for the Katowice conurbation in southern Poland [Grząba 2014].
The dominant genetic level of this sample is the E-eluvial requirement level, as evidenced by the small amount of dark colourations caused by humus compounds. The structure for the tested sample determines its character as dense (Figure 2). This type of soil is clearly disadvantageous in terms of its use in agriculture [Zawadzki 1999].

The list of brown and loamy soil parameters, marked in the earlier studies of the author, are shown in Table 2.

\section{METHODS}

Own location for geochemical studies was used to conduct research, whose diagram is presented in Figure 3.

In order to perform the markings, the collected soil samples were placed in a PVC plastic pipe with a height of $50 \mathrm{~cm}$, diameter of $100 \mathrm{~mm}$ up to the height constituting approx. $3 / 4$ of the pipe length. The bottom of the tube was secured with a sieve. Then, the space over the soil surface was filled by leachate from the landfill in the amount of approx. $3 \mathrm{dm}^{3}$ using a plastic funnel. The infiltrating leachate has moved through the soil layer and was collected in the filtrate form in a dish placed under the tube of the sieve. The leachate was returned a few times for a longer impact, i.e., shocking the soil with the leachate. The assay time was about 3 weeks. The experiment was carried out in the Physical-Chemical Analysis Laboratory belonging to the Department of Technology and Equipment for Waste Management at the Department of Environmental Engineering and Energy of the Silesian University of Technology in Gliwice. The research was of the model character for the verification of the migration manner of the landfill leachate of the upper soil levels

Tabela 2. Soil properties used in research

\begin{tabular}{|c|c|c|c|}
\hline Soil parameter & Unit & $\begin{array}{l}\text { Parameter before leacahte } \\
\text { infiltration - browny soil }\end{array}$ & $\begin{array}{c}\text { Parameter before leachate } \\
\text { infiltration - loamy soil }\end{array}$ \\
\hline Content of organic (X) & [\%] & 37.76 & 18.62 \\
\hline Content of Sulfur $\mathrm{S}_{\mathrm{a}}$ & [\%] & 1.628 & 1.028 \\
\hline Mineral Acidity $\left(\mathrm{K}_{\mathrm{p}}\right)$ & {$\left[\mathrm{mval} \cdot \mathrm{dm}^{-3}\right]$} & p.p.o* & p.p.o* \\
\hline Total acidity $\left(\mathrm{K}_{\mathrm{m}}\right)$ & {$\left[\mathrm{mval} \cdot \mathrm{dm}^{-3}\right]$} & 1.6 & 0.37 \\
\hline Mineral Alkalinity $\left(Z_{p}\right)$ & {$\left[\mathrm{mval} \cdot \mathrm{dm}^{-3}\right]$} & 1.6 & 2.37 \\
\hline General Alkalinity $\left(Z_{m}\right)$ & {$\left[\mathrm{mval} \cdot \mathrm{dm}^{-3}\right]$} & p.p.o* & p.p.o* \\
\hline $\mathrm{pH}$ & {$[-]$} & 7.99 & 8.14 \\
\hline Content of chlorides $\left(\mathrm{X}_{\mathrm{Cl}}\right)$ & {$\left[\mathrm{mg} \mathrm{Cl}^{-} \cdot \mathrm{dm}^{-3}\right]$} & 0.00805 & 0.0184 \\
\hline Permeability coeficcient $\left(\mathrm{K}_{\mathrm{t}}\right)$ & {$\left[\mathrm{cm} \cdot \mathrm{s}^{-1}\right]$} & 0.0915 & 0.0105 \\
\hline Water capacity & [\% by weight] & 36.3 & 25.89 \\
\hline
\end{tabular}

\footnotetext{
* p.p.o - below the quantification level.
} 

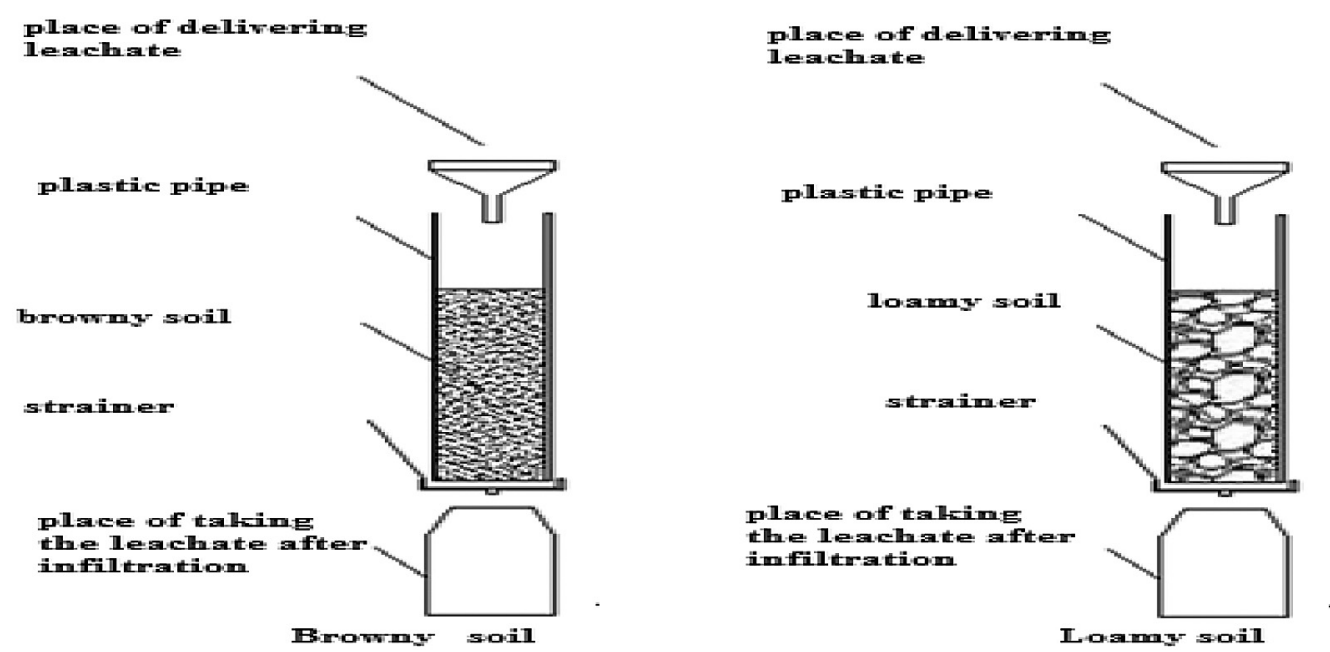

Figure 3. General scheme of the research bench for geochemical studies [Gałko 2014]

towards the lower ones. The study assessed the potential impact of landfill leachate infiltration on the change of chemical parameters of the soil. Markings were performed in accordance with the existing PN norms concerning the chemical analyses of the soil and sewage, in force in Poland.

\section{RESULTS}

The Table 3 presents results of chemical parameters indicators of brown and loamy soil before and after contamination with the leachate.

In order to assess the impact of the landfill leachate on the plants, a phytotoxicity test was performed using the garden cress. This study measured the growth of the root part of cress after 24 hours of contact with the analysed soil types. The determination was performed by seeding the garden cress seeds on the clean brown soil and on the soil after contamination with the landfill leachate. The sample for the loamy soil in both variants was analogously performed. The control sample was grown on a substrate, which was the distilled water [PN-EN16086;2;2011]. The results of the growth of the root part of the cress grown in the control sample was compared to the results obtained from brown soil samples of the stony and loamy grounds. The stimulation in the phytotoxicity test was determined as the percent of the plant root part growth (Table 4).

Table 3. Results of chemical parameters indicators of brown and loamy soil before and after contamination with the leachate

\begin{tabular}{|c|c|c|c|c|c|c|c|}
\hline \multicolumn{2}{|c|}{ The name of the soil } & \multicolumn{6}{|c|}{ The brown and loamy soil before and after infiltration } \\
\hline \multicolumn{2}{|c|}{ Place of collecting sample } & \multicolumn{3}{|c|}{$\begin{array}{c}\text { Forest complex of mountaing Lipowski } \\
\text { Groń (734 height) community: Brenna. } \\
\text { Cieszyn province: Silesian Region - } \\
\text { browny soil }\end{array}$} & \multicolumn{3}{|c|}{$\begin{array}{c}\text { Katowice Forest Park. district Brynów. } \\
\text { City Katowice Silesian region - } \\
\text { loamy soil }\end{array}$} \\
\hline Soil parameter & Unit & $\begin{array}{l}\text { the } \\
\text { parameter } \\
\text { before } \\
\text { infiltration }\end{array}$ & $\begin{array}{l}\text { the } \\
\text { parameter } \\
\text { after } \\
\text { infiltration }\end{array}$ & $\begin{array}{l}\text { difference of } \\
\text { parameters }\end{array}$ & $\begin{array}{l}\text { the } \\
\text { parameter } \\
\text { before } \\
\text { infiltration }\end{array}$ & $\begin{array}{l}\text { the } \\
\text { parameter } \\
\text { after } \\
\text { infiltration }\end{array}$ & $\begin{array}{l}\text { difference of } \\
\text { parameters }\end{array}$ \\
\hline Content of organic $(\mathrm{X})$ & [\%] & 37.76 & 36.74 & $-2.77 \%$ & 18.62 & 23.66 & $27 \%$ \\
\hline Content of Sulfur $\mathrm{S}_{\mathrm{a}}$ & [\%] & 1.628 & 0.242 & $-85.13 \%$ & 1.028 & 0.241 & $-326 \%$ \\
\hline Mineral Acidity $\left(\mathrm{K}_{\mathrm{p}}\right)$ & {$\left[\mathrm{mval} \cdot \mathrm{dm}^{-3}\right]$} & \multicolumn{3}{|c|}{ below the limit quantification } & \multicolumn{3}{|c|}{ below the limit quantification } \\
\hline Total Acidity $\left(\mathrm{K}_{\mathrm{m}}\right)$ & {$\left[\mathrm{mval} \cdot \mathrm{dm}^{-3}\right]$} & 1.6 & 1.13 & $-30 \%$ & 0.37 & 0 & $-100 \%$ \\
\hline Mineral Alkalinity $\left(Z_{p}\right)$ & {$\left[\mathrm{mval} \cdot \mathrm{dm}^{-3}\right]$} & 1.6 & 11.33 & $608 \%$ & 2.37 & 11.67 & $392 \%$ \\
\hline General Alkalinity $\left(Z_{m}\right)$ & {$\left[\mathrm{mval} \cdot \mathrm{dm}^{-3}\right]$} & \multicolumn{3}{|c|}{ below the limit quantification } & \multicolumn{3}{|c|}{ below the limit quantification } \\
\hline $\mathrm{pH}$ & {$[-]$} & 7.99 & 9.05 & $13 \%$ & 8.14 & 8.94 & $+9.82 \%$ \\
\hline Content of chlorides $\left(\mathrm{X}_{\mathrm{Cl}}\right)$ & {$\left[\mathrm{mg} \mathrm{Cl}^{-} \cdot \mathrm{dm}^{-3}\right]$} & 0.00805 & 0.59 & $7200 \%$ & 0.0184 & 0.48 & $2608 \%$ \\
\hline Permeability coeficcient $\left(\mathrm{K}_{\mathrm{t}}\right)$ & {$\left[\mathrm{cm} \cdot \mathrm{s}^{-1}\right]$} & 0.0915 & 0.0915 & - & 0.0105 & 0.1015 & - \\
\hline Water capacity & [\% by weight] & 36.3 & 36.3 & - & 25.89 & 25.89 & - \\
\hline
\end{tabular}


Table 4. The results of the phytotoxicity test

\begin{tabular}{|c|c|c|c|c|c|c|c|}
\hline \multirow[b]{2}{*}{ Soil parameter } & \multicolumn{3}{|c|}{ The browny soil with stony ground } & \multicolumn{3}{|c|}{ The loamy soil } & \multirow[b]{2}{*}{ Unit } \\
\hline & $\begin{array}{c}\text { the parameter } \\
\text { before } \\
\text { infiltration }\end{array}$ & $\begin{array}{l}\text { the parameter } \\
\text { after infiltration }\end{array}$ & $\begin{array}{l}\text { difference of } \\
\text { parameters }\end{array}$ & $\begin{array}{c}\text { the parameter } \\
\text { before } \\
\text { infiltration }\end{array}$ & $\begin{array}{l}\text { the parameter } \\
\text { after infiltration }\end{array}$ & $\begin{array}{l}\text { difference of } \\
\text { parameters }\end{array}$ & \\
\hline Phytotoxicity & 20.24 & 73.4 & +262.64 & 13.28 & 72.4 & 445 & [\%] \\
\hline
\end{tabular}

Figures 4-10 present graphs showing the results of studies in the form of chemical parameter changes of the tested soils as a result of their contamination with the landfill leachate.

The content of the organic substance decreased from the value of 37,76 to $36,74 \%$ in the brown soil, while in the loamy soil increased to the value from $18,62 \%$ to $23,66 \%$. The increase in mineral alkalinity in the case of brown soil was from the value of 1,6 to $11,33 \mathrm{mval} / \mathrm{dm}^{3}$, while the increase of $\mathrm{pH}$ was from the value of 7,99 to 9,05 . In the case of the brown soil the increase of mineral alkalinity was from the value of 2,37 to $11,67 \mathrm{mval} / \mathrm{dm}^{3}$, while the $\mathrm{pH}$ increase was from 8,14 to 8,94 . A significant amount of chlorides contained in the leachate was retained in the soil, what was manifested by the increase from the value of $0,00805 \mathrm{mg} \mathrm{Cl} \cdot \mathrm{dm}^{-3}$ to 0,59 $\mathrm{mg} \mathrm{Cl}^{-} \cdot \mathrm{dm}^{-3}$ in the case of brown soil. A smaller increase was observed in the case of loamy soil, where the maximum chloride content was 0,48 $\mathrm{mg} \mathrm{Cl}^{-} \cdot \mathrm{dm}^{-3}$.

Table 5 presents the summary of data concerning the original landfill leachate parameters and after the infiltration by soil.

A change of five out of seven studied parameters of the leachate was stated. In the case of three indicators, i.e. total acidity, mineral alkalinity and chloride content, after infiltration by soil, their contents have significantly dropped. Small changes of the $\mathrm{pH}$ were noted - for brown soil the decrease of $4,55 \%$, while for loamy soil the increase of $0,33 \%$. The total hardness of the leachate was more than doubled in the brown soil, while in the loamy soil it increased by less than $20 \%$.

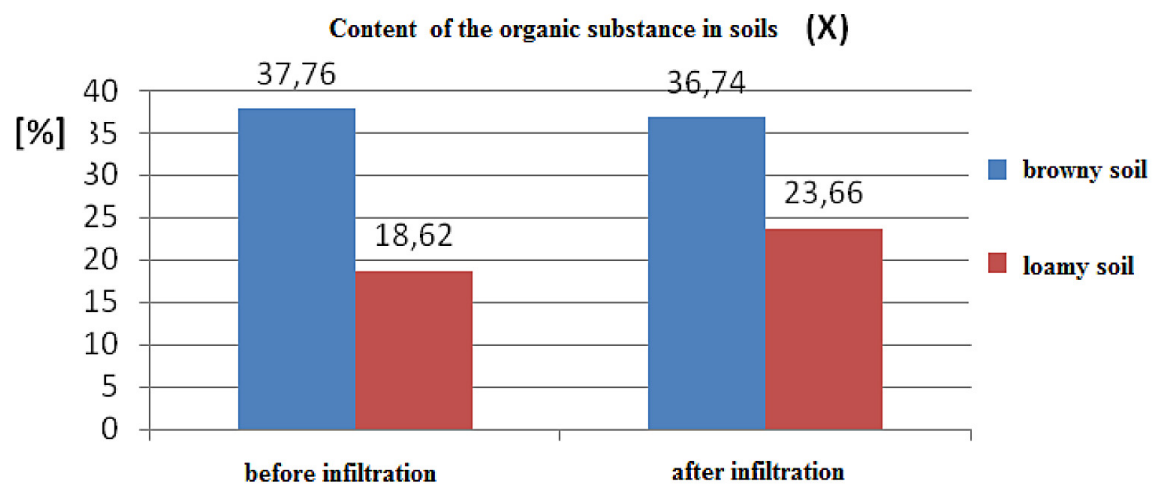

Figure 4. Changes of the organic substance contents in the brown and loamy soil

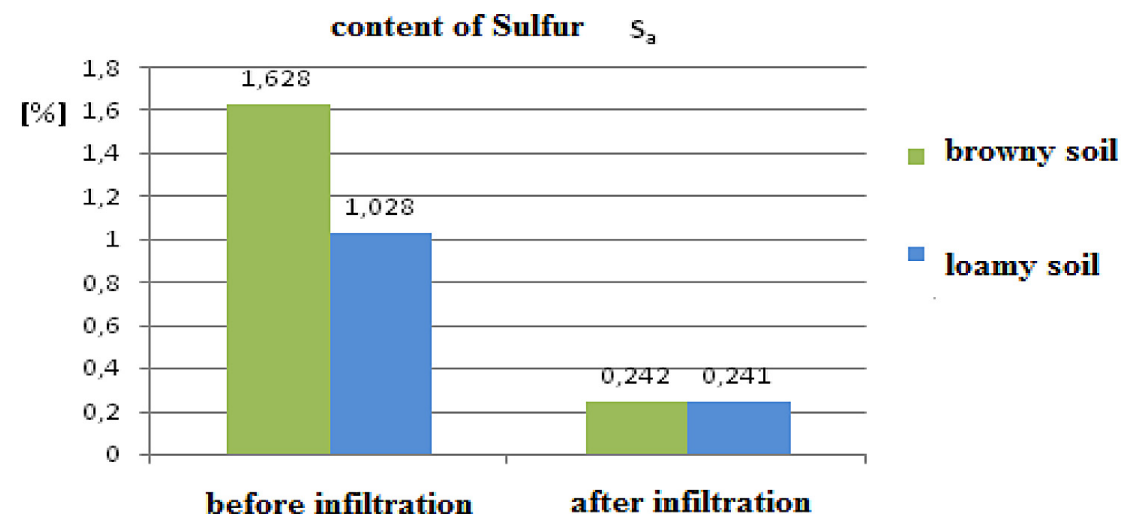

Figure 5. Changes of the sulphur contents in the brown and loamy soils $\left(\mathrm{S}_{\mathrm{a}}\right)$ 
Table 5. Changes of the landfill leachate parameters before and after its infiltration by the brown soil with the stony ground [Gałko 2014]

\begin{tabular}{|c|c|c|c|c|c|c|c|}
\hline \multirow[b]{2}{*}{$\begin{array}{l}\text { Leachate } \\
\text { parameter }\end{array}$} & \multicolumn{3}{|c|}{ Browny soil with stony ground } & \multicolumn{3}{|c|}{ Loamy soil } & \multirow[b]{2}{*}{ Unit } \\
\hline & $\begin{array}{c}\text { the parameter } \\
\text { before infiltration }\end{array}$ & $\begin{array}{l}\text { the parameter } \\
\text { after infiltration }\end{array}$ & $\begin{array}{c}\text { difference of } \\
\text { parameters }\end{array}$ & $\begin{array}{c}\text { the parameter } \\
\text { before } \\
\text { infiltration }\end{array}$ & $\begin{array}{l}\text { the parameter } \\
\text { after infiltration }\end{array}$ & $\begin{array}{c}\text { difference of } \\
\text { parameters }\end{array}$ & \\
\hline Mineral acidtiy & p.p.o* & p.p.o & 0 & p.p.o* & p.p.o* & 0 & {$\left[\mathrm{mval} \cdot \mathrm{dm}^{-3}\right]$} \\
\hline General acidity & 1,867 & 0,87 & $-53,5 \%$ & 1,867 & 0 & $-100 \%$ & {$\left[\mathrm{mval} \cdot \mathrm{dm}^{-3}\right]$} \\
\hline Mineral alkalinity & 18,97 & 7,77 & $-59,05 \%$ & 18,97 & 0,7 & $-2610 \%$ & {$\left[\mathrm{mval} \cdot \mathrm{dm}^{-3}\right]$} \\
\hline General alkalinity & p.p.o & p.p.o & 0 & 0 & 10,97 & $100 \%$ & {$\left[\mathrm{mval} \cdot \mathrm{dm}^{-3}\right]$} \\
\hline $\mathrm{pH}$ & 8,66 & 8,229 & $-4,55 \%$ & 8,66 & 8,689 & $0,33 \%$ & {$[-]$} \\
\hline Content of chorides & 1,261 & 0,540 & $-57 \%$ & 1,261 & 0,559 & $-56 \%$ & {$\left[\mathrm{mg} \mathrm{Cl}^{-} \cdot \mathrm{dm}^{-3}\right]$} \\
\hline General hardness & 0,64 & 1,293 & $+102 \%$ & 0,64 & 0,767 & $19,84 \%$ & {$\left[\mathrm{mval} \cdot \mathrm{dm}^{-3}\right]$} \\
\hline
\end{tabular}

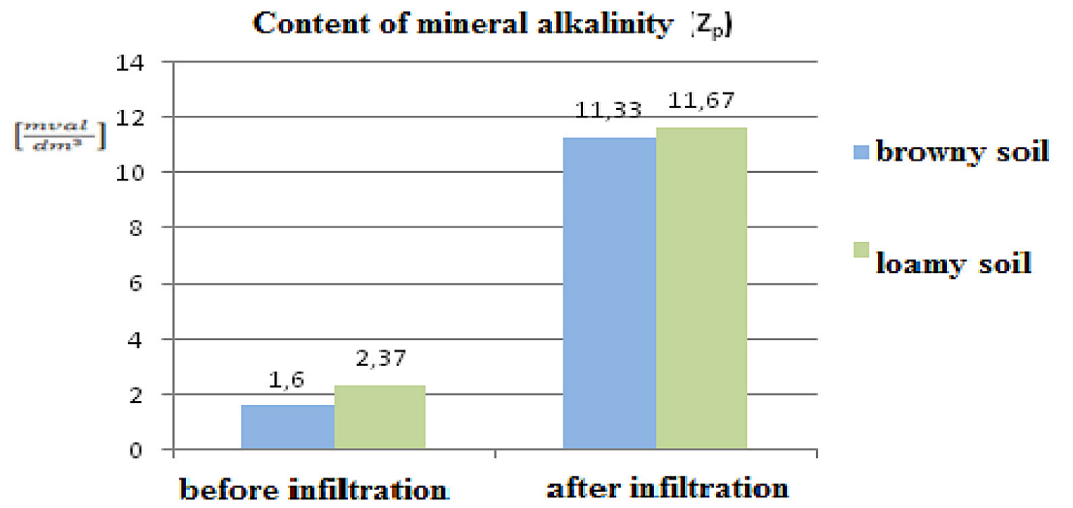

Figure 6. Changes in mineral alkalinity content in brown soil and loamy soil $\left(\mathrm{Z}_{\mathrm{p}}\right)$

Total acidity in soil $\left(K_{m}\right)$

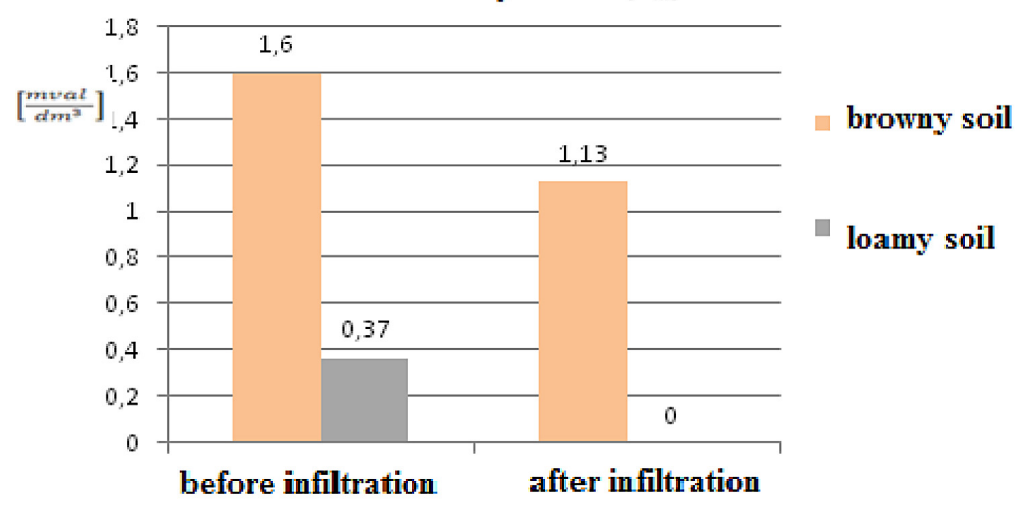

Figure 7. Changes in total acidity in brown soil and loamy soil

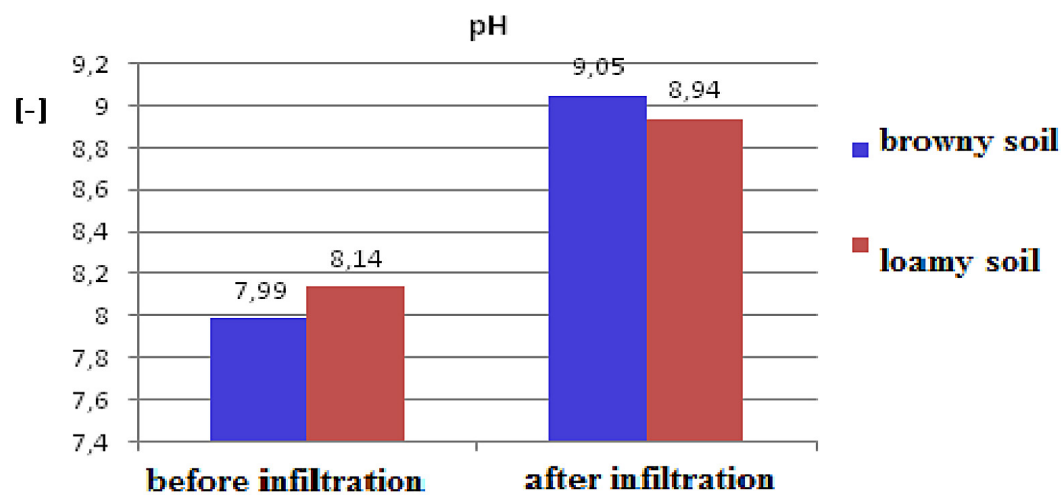

Figure 8. Changes in $\mathrm{pH}$ in brown soil and loamy soil 


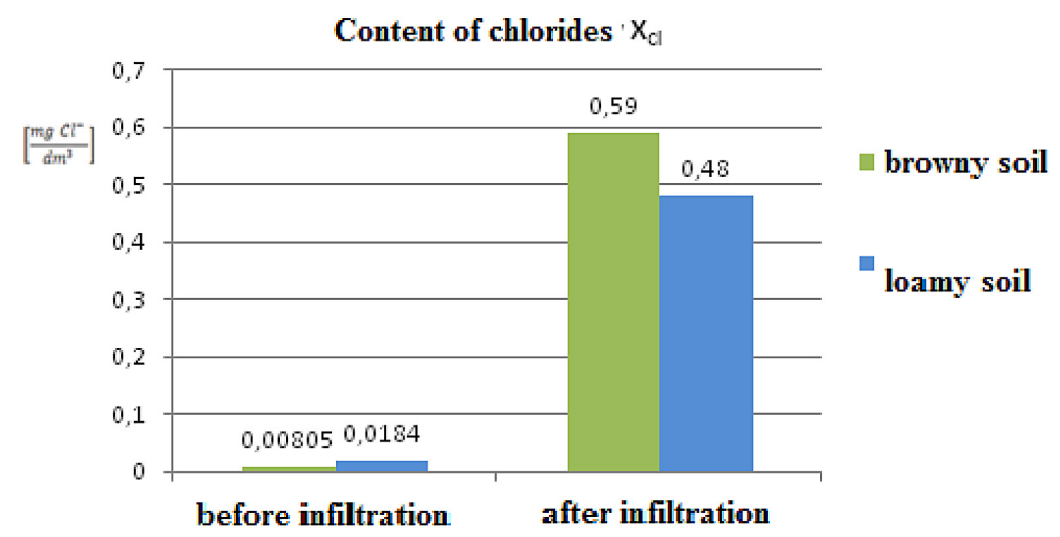

Figure 9. Changes in the chloride content $\left(\mathrm{X}_{\mathrm{Cl}}\right)$ in brown soil and in loamy soil

Phytotoxicity

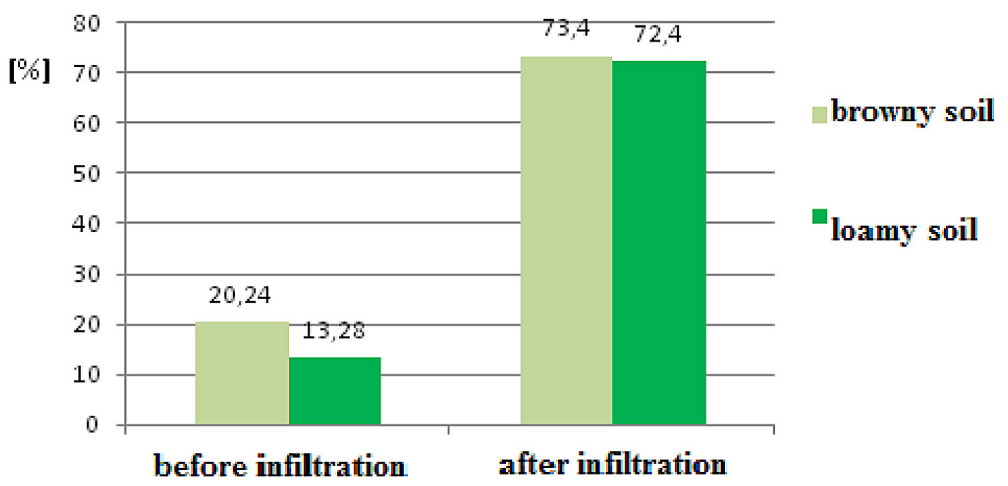

Figure 10. Changes of soil stimulant properties by the phytotoxicity test on the example of brown soil and loamy soil

\section{CONCLUSIONS}

The landfill leachate infiltrating the soil layer affected significantly the changes of its chemical parameters. It was stated that the total acidity, mineral alkalinity and chloride content in the studied soils reduced after the contamination with the landfill leachate. While the chloride content, total hardness and total alkalinity increased.

The leachate infiltration affected the increase of pollution, especially in loamy soil which is less permeable than brown. The effect of the landfill leachate infiltration was also the reduction of mineral substances due to their flushing from the soil profile.

It was found that the studied landfill leachate contained substantial amounts favourable to the plant growth. The root parts of cress grown on the soil contaminated by the leachate were greater compared to the root size of cress growing on clean soil. The increase of the root part of cress also proves that the leachate did not contain toxic substances for plants.

\section{REFERENCES}

1. Bojanowicz-Bablok A. 2012. External effects associated with the nuisance of communal waste landfills. Institute of Environmental Protection - National Research Institute, Archives of Waste Management and Environmental Protection, 14 (1), 11-20.

2. Den Boer E., Czarnecka W., Kowalski Z., Kulczycka J., Szpadt R., 2009. The amount and composition of communal waste produced in households of large Polish cities. Archives of Waste Management and Environmental Protection, 11(4), 75-90.

3. Renou S., Givaudan J.G., Poulain S., Dirassouyan F, Moulin P. 2008. Landfill leachate treatment: Review and opportunity. Journal of Hazardous Materials $470,468-493$

4. Koc-Jurczyk J., Różak J., 2011. The composition of leachate from the communal waste reclaimed landfill. Inżynieria Ekologiczna, 27, 72-75.

5. Zawadzki S. 1999. Soil Science, National Agricultural and Forestry Publishing House, Warsaw.

6. Documentation made available by the company PPHU „KOMART” in Knurów, http://www. 
komart.pl/pliki/Druki/pozwolenie.pdf (access February 12,2014$)$.

7. Regulation of the Minister of Environment of July 24, 2006 on the conditions, which should be met while introducing sewage to water or soil on substances particularly harmful to the aquatic environment (Journal of Laws 2006 no. 137. item 984).

8. Grząba E. Katowice Forest Park, website: http:// www.parki.org.pl/parki-miejskie/katowicki-parklesny (access February 22, 2014)

9. Mayer J. 2000. Soil testing textbook. PhyweSysteme GMBH D-37070 Gottingen, Germany, 2-19.

10. PN-EN 16086-2:2011 - Measures improving soil and growing substrates. Determination of plant reactions. Part 2: Study on Petri dishes with cress.

11. Barański M. 1995. Beskid Śląski. The chains of Klimczok and Równica. Publisher PTTK "Kraj”, Warsaw 1995.
12. Jamróz A., 2012. Proper construction, exploitation and reclamation of communal waste landfills in accordance with the Polish law. Technical magazine (Environment), Ed. of the Cracow University 1-Ś, 4 (109). 87-100.

13. Gałko G., 2014. The assessment of the soil environment on the landfill leachate, Problems of environmental engineering, XXXIV International Symposium of Bolesław Krzysztofik AQUA 2014, Płock, 208-214.

14. Bojanowicz-Bablok A., 2012. External effects associate with nuisance of landfills for the environment, Archives of Waste Management and Environmental Protection, 12 (1), 12-22.

15. Alwaeli M, 2005. Treatment of communal waste in the light of requirements of the National Waste Management Plan. Archives of Waste Management and Environmental Protection, vol. 2, 81-90. 